Jurnal Ilmiah "Kreatif" Vol. X No. 2 Juli 2015

"Jurnal Studi Pemikiran Pendidikan Agama Islam"

\title{
GURU PENDIDIKAN AGAMA ISLAM DAN TRANSFORMASI NILAI KEISLAMAN DALAM PERUBAHAN SOSIAL
}

\author{
Oleh: Sukrin ${ }^{\star}$
}

\begin{abstract}
Abstrak:
Kegagalan pendidikan nasional itu disebabkan oleh penerapan konsep pendidikan yang sedikit banyak telah mengabaikan pendidikan watak dan kemampuan bernalar atau dengan kata lain telah mengabaikan transformasi nilai moral. Pendidikan seharusnya diarahkan untuk membangun watak bangsa dan "moral feeling." Agenda pendidikan masa depan harus mulai mengutamakan pendidikan yang mampu menciptakan manusia bermoral, dengan tetap memaksimalkan peningkatan kompetensi guru. Peran guru PAI dalam upaya menanamkan nilai keislaman diharapkan mampu memberikan modal sosial pada peserta didik agar dapat menyesuaikan diri terhadap perubahan sosial yang terjadi.
\end{abstract}

Kata Kunci: Guru, PAI, Nilai, Keislaman, Perubahan Sosial.

\section{Pendahuluan}

Pendidikan agama di Indonesia, oleh banyak kalangan dinilai telah gagal total. Kegagalan itu bisa ditengarai dari maraknya kasus korupsi, vandalisme, tawuran antar pelajar, meningkatnya angka kehamilan diluar nikah, aborsi dikalangan remaja dan pelajar, meningkatnya kasus kriminalitas dan sebagainya, dimana pelakunya adalah orang-orang beragama dan terpelajar. Tidak heran kemudian banyak yang menyoroti masalah ini dari berbagai perspektif. Akan tetapi perlu disadari bahwa tidak hanya pendidikan agama Islam yang mengalami kegagalan, tetapi semua pendidikan agama. Hal ini dibuktikan dengan pelaku tindakan kriminal dan kebobrokan moral juga berasal dari berbagai penganut agama.

Kegagalan pendidikan agama dipengaruhi oleh banyak faktor, termasuk dua diantaranya yang terpenting adalah faktor keteladanan dalam keluarga dan faktor sistem sosial yang berlaku di tengah masyarakat. Meskipun tudingan yang mengarah ke sekolah dan guru

*Penulis adalah Dosen Tetap IAI Muhammadiyah Bima 
Jurnal Ilmiah "Kreatif" Vol. X No. 2 Juli 2015

"Jurnal Studi Pemikiran Pendidikan Agama Islam"

tetap sulit dihindari. Betapapun guru agama berargumen bahwa tidak mungkin membentuk akhlak anak hanya dalam beberapa jam mata pelajaran di sekolah, kebanyakan orang tua akan mengatakan tidak peduli karena mereka merasa sudah menyerahkan pendidikan anaknya ke sekolah. Dalam waktu yang relatif singkat, di tengah lingkungan sosial (keluarga-masyarakat-sekolah) yang belum tentu saling mendukung, guru dan sekolah dituntut untuk menghasilkan output pendidikan agama yang tak bercela. Inilah tantangan besar pendidikan agama di sekolah. ${ }^{1}$

Untuk menghadapi tantangan dan tujuan tersebut, jelas dibutuhkan solusi cerdas dari guru agama dan pihak sekolah, tentu saja dengan dukungan para stakeholders dan pemerintah melalui kebijakankebijakan yang membantu terciptanya situasi yang kondusif bagi penyelenggaraan pendidikan agama Islam. Dalam konteks ini perlu fokus pada hakikat guru pendidikan agama Islam, nilai-nilai dasar apa saja yang hendak ditransformasikan oleh guru pendidikan agama Islam pada siswa. Sebelum itu, penulis akan terlebih dahulu mengupas problem-problem yang dihadapi masyarakat dewasa ini, kemudian menawarkan jalan keluar.

\section{Pendidikan Agama Islam dan Problematika Sosial Masyarakat}

Sebagian besar penduduk Indonesia (baca: umat Islam) kini sedang berada di tengah berbagai persoalan yang teramat kompleks. Ibarat orang sakit, bangsa ini mengidap komplikasi penyakit yang demikian akut. Saat ini tengah mengalami berbagai macam krisis yang mebuatnya semakin terpuruk. Krisis ekonomi, kepemimpinan, kepercayaan, kedamaian, kesejahteraan dan sebagainya. Semua itu sesungguhnya bersumber pada satu krisis saja, yaitu krisis moral.

Secara umum, Muhyidin Albarobis menguraikan enam "kerusakan" yang diidap oleh bangsa Indonesia. Pertama, "prestasi" bangsa Indonesia di mata dunia. Menurut Albarobis, dalam banyak hal Indonesia kini telah menjadi bangsa pacundang yang hampir selalu kalah disetiap persaingan antar bangsa. Jika dahulu bangsa ini adalah bangsa yang besar dan disegani, kini bahkan negara kecil sama sekali pun tidak takut mengancam kadaulatan Indonesia. Ironisnya, saat ini dunia mengenal bangsa Indonesia dengan "prestasi" yang amat memalukan: korupsi. Disamping itu juga sangat rendah di bidang pembangunan sumber daya manusia yang mencakup kualitas kesehatan, tingkat

1 Sutrisno dan Muhyidin Albaroris, Pendidikan Islam Berbasis Problem Sosial, (Yogyakarta: Ar-Ruzz Media, 2012), 76 
Jurnal Ilmiah "Kreatif" Vol. X No. 2 Juli 2015

"Jurnal Studi Pemikiran Pendidikan Agama Islam"

pendidikan, dan kondisi ekonomi (pendapatan). Kedua, pejabat publik yang tunamoral. Penyalahgunaan kekuasaan yang seharusnya diarahkan untuk kepentingan rakyat diarahkan untuk memenuhi kebutuhan pribadi dan kelompok. Lebih ironis lagi ketika kekuasaan digunakan untuk menindas rakyat. Ketiga, ketimpangan penegakan hukum. Di Indonesia, keadilan masih menjadi barang mewah yang tidak dapat dibeli oleh rakyat kecil dan miskin. Keempat, masyarakat yang kalap. Konflik antar suku, agama dan etnis masih marak terjadi, bahkan hampir membudaya. Disamping itu konflik kepentingan dan politik juga turut mewarnai kondisi sosial masyarakat di Indonesia. Kelima, guru yang tidak patut di tiru. Guru adalah ujung tombak peniddikan, kepadanya diharapkan memberi banyak kemajuan bangsa. Potret guru yang tidak patut ditiru seperti hilangnya keteladanan, kepercayaan diri, dan kejujuran. Keenam, generasi muda yang sakit. Dalam soal prestasi, anak muda Indonesia tidak kalah hebat dibandingkan anak-anak dari negara lain. Namun di sisi lain, hal yang paling memprihatinkan adalah moralitas yang sudah mencapai titik nadir. ${ }^{2}$

Keenam serpihan masalah bangsa Indonesia yang diuraikan oleh Albarobis di atas relatif merepresentasikan problem yang dihadapi oleh umat Islam, khususnya di Indonesia. Daftar itu sesungguhnya masih bertambah panjang dengan memasukkan persoalan kemiskinan, pengangguran, pendidikan yang mahal, kerusakan lingkungan dan sebagainya.

Menurut Ismail Raji al-Faruqi, secara umum keadaan umat Islam di dunia benar-benar terpuruk baik secara fisik maupun mental. Citra umat Islam selalu dipojokkan dengan sebutan agresif, destruktif, ekstrimis, eksklusif, teroris dan sebagainya. Sedangkan menurut Fazlur Rahman, pokok pangkal kemunduran peradaban Islam adalah adanya dikotomi ilmu, yaitu ilmu agama (Islam) di satu sisi dan ilmu modern (umum) di sisi lain. Dikotomi ilmu tersebut pada perkembangannya mengakibatkan terjadinya dualisme dalam sistem pendidikan tradisional dan sistem pendidikan sekuler modern. ${ }^{3}$

Berdasarkan dari uraian di atas, salah satu langkah yang perlu dikembangkan adalah dengan mengembangkan ilmu (baca: pendidikan) agama Islam pada wilayah praksis, sehingga ilmu-ilmu agama Islam mampu memberikan kontribusi yang paling berharga bagi kepentingan kemanusiaan sebagaimana yang pernah dilakukan oleh ilmuwanilmuwan Muslim sebelumnya. Berpadunya aspek idealisme dan realisme

\footnotetext{
${ }^{2}$ Muhyidin Albarobis, Mendidik Generasi Bangsa, (Yogyakarta: Pedagogia, 2012), 21-32

${ }^{3}$ Sutrisno dan Muhyidin Albaroris, Pendidikan..., 85
} 
Jurnal Ilmiah "Kreatif" Vol. X No. 2 Juli 2015 "Jurnal Studi Pemikiran Pendidikan Agama Islam"

atau rasionalisme dan empirisme dalam paradigma keilmuan Islam perlu dikembangkan.

Adanya anggapan bahwa pendidikan agama Islam masih merupakan subsistem dari sistem pendidikan secara umum, harus dilihat dari rancang bangun bagi para pakar pendidikan Islam untuk melakukan rekonstruksi pendidikan Islam tersebut.

\section{Peran dan Kompetensi Guru Pendidikan Agama Islam}

Sebagai suatu sistem, pendidikan memiliki sejumlah komponen yang saling berkaitan antara satu dengan yang lainnya untuk mencapai tujuan yang ditetapkan. Komponen pendidikan tersebut antara lain komponen kurikulum, guru, metode, sarana dan prasarana, serta evaluasi. Dari sekian komponen pendidikan tersebut, guru merupakan komponen terpenting dalam pendidikan, terutama dalam mengatasi berbagai permasalahan yang berkaitan dengan peningkatan mutu pendidikan.

Dalam menjalani kehidupan, guru menjadi seorang tokoh dan panutan bagi peserta didik dan lingkungan sekitarnya. Abduhzen mengungkapkan bahwa Imam Al-Ghazali menempatkan profesi guru pada posisi tertinggi dan termulia dalam berbagai tingkat pekerjaan masyarakat. Guru mengemban dua misi sekaligus, yaitu tugas keagamaan dan tugas sosiopolitik. Adapun yang dimaksud dengan tugas keagamaan menurut Al-Ghazali adalah tugas guru ketika ia melakukan kebaikan dengan menyampaikan ilmu pengetahuan kepada manusia guru merupakan makhluk termulia di muka bumi. Sedangkan yang dimaksud dengan tugas sosiopolitik adalah bahwa guru membangun, memimpin, dan menjadi teladan yang menegakkan keteraturan, kerukunan, dan menjamin keberlangsungan masyarakat. ${ }^{4}$

Sebagai individu yang berkecimpung dalam pendidikan, guru harus memiliki kepribadian yang mencerminkan seorang pendidik. Tuntutan akan kepribadian sebagai pendidik kadang-kadang dirasakan lebih berat dibanding profesi lainnya. Ungkapan yang sering digunakan adalah bahwa "guru bisa digugu dan ditiru". Digugu maksudnya bahwa pesan-pesan yang disampaikan guru bisa dipercaya untuk dilaksanakan dan pola hidupnya bisa ditiru atau diteladani. Untuk itu, guru haruslah mengenal nilai-nilai yang dianut dan berkembang di masyarakat tempat

\footnotetext{
${ }^{4}$ E. Mulyasa, Standar Kompetensi dan Sertifikasi Guru, (Bandung: Remaja Rosdakarya, 2007), 174
} 
Jurnal Ilmiah "Kreatif" Vol. X No. 2 Juli 2015

"Jurnal Studi Pemikiran Pendidikan Agama Islam"

melaksanakan tugas dan bertempat tinggal. Apabila ada nilai yang bertentangan dengan nilai yang dianutnya, maka haruslah ia menyikapinya dengan hal yang tepat sehingga tidak terjadi benturan nilai antara guru dengan masyarakat. Apabila terjadi benturan antara keduanya maka akan berakibat pada terganggunya proses pendidikan. Oleh karena itu, seorang guru haruslah memiliki kompetensi sosial agar nantinya apabila terjadi perbedaan nilai dengan masyarakat, ia dapat menyelesaikannya dengan baik sehingga tidak menghambat proses pendidikan. $^{5}$

Sementara itu medan tugas para guru semakin menantang. Hal ini terjadi karena kemajuan dibidang ilmu pengetahuan dan teknologi serta perubahan cara pandang dan pola hidup masyarakat yang menghendaki strategi dan pendekatan dalam proses pembelajaran yang berbeda-beda, disamping materi pelajaran itu sendiri. Dengan kondisi perkembangan masyarakat seperti ini, maka mendidik merupakan tugas berat dan memerlukan individu yang cukup memiliki kemampuan untuk tanggung jawab tersebut.

Untuk menjadi seorang guru yang dapat mempengaruhi anak didik ke arah kebahagiaan dunia dan akhirat tidaklah ringan, artinya ada syarat-syarat yang harus dipenuhi. ${ }^{6}$ Seorang pendidik dituntut untuk memiliki kompetensi secara menyeluruh. Merujuk pada Rasulullah, seorang pendidik seharusnya memiliki sifat sidiq, amanah, tabligh, dan fathanah. Sifat sidiq ini mencerminkan kompetensi kepribadian seorang pendidik yang menampilkan diri sebagai pribadi yang jujur, berakhlak mulia dan teladan bagi peserta didik dan masyarakat. Sifat amanah, melahirkan kompetensi sosial pendidik yaitu mampu bersikap inklusif, bertindak ojektif serta tidak diskriminatif. Sifat tabligh, menghasilkan kompetensi pedagogik pendidik dengan menguasai karakteristik peserta didik dari aspek fisik, moral sosial, emosional dan intelektual. Sifat fathanah, terrefleksi pada kompetensi profesional pendidik dalam bentuk menguasai materi, struktur, konsep dan pola pikir keilmuan. ${ }^{7}$

Para tokoh pendidikan telah banyak merumuskan konsep pendidikan termasuk tentang kompetensi pendidik dan etika peserta didik, serta sifat-sifat yang harus dimiliki oleh keduanya dalam proses belajar mengajar. Seorang pendidik dituntut mampu memainkan peran

\footnotetext{
${ }^{5}$ Ibid., 175

${ }^{6}$ Zakiah Darajat, Ilmu Pendidikan Islam, (Jakarta: Bumi Aksara, 2008), 40

${ }^{7}$ Ahmad Taufiq dan Muhammad Rohmadi (ed), Pendidikan Agama Islam, (Surakarta: Yuma Pustaka, 2011), 220-224
} 
Jurnal Ilmiah "Kreatif" Vol. X No. 2 Juli 2015

"Jurnal Studi Pemikiran Pendidikan Agama Islam"

dan fungsinya dalam menjalankan tugas kependidikannya, sehingga dapat menempatkan dirinya sesuai dengan kepentingan sebagai individu, anggota masyarakat, warga negara dan pendidik sendiri. Antara satu peran dan peran lainnya harus ditempatkan secara proporsional. Kadangkala seorang pendidik menganggap bahwa tugas sesungguhnya adalah memberikan dan memindahkan ilmu pengetahuan (transfer of knowledge) saja, namun selain itu pendidik juga bertanggung jawab atas pengelolaan (manager of learning), pengarah (director of learning), fasilitator dan perencana (the planer of future society). ${ }^{8}$

Guru menjadi bagian dari kehidupan siswa, di mana siswa menjadikan guru sebagai role model (contoh teladan) dari berbagai aspek. ${ }^{9}$ Jadi tidak mengherankan jika guru di sekolah senantiasa menjadi tumpuan teladan siswa dai segi pakaian, tingkah laku, dan sebagainya.

\section{Nilai-nilai dalam Perspektif Keislaman}

Pendidikan Agama Islam berkenaan dengan tanggung jawab bersama. Sehingga pendidikan merupakan sebuah usaha yang secara sadar dilakukan oleh guru mempengaruhi siswa dalam rangka pembentukan manusia beragama yang diperlukan dalam pengembangan kehidupan beragama dan sebagai salah satu sarana pendidikan Nasional dalam rangka meningkatkan ketaqwaan terhadap Tuhan Yang Maha Esa. ${ }^{10}$ Pendidikan Agama Islam pada dasarnya adalah pendidikan yang bertujuan untuk membentuk pribadi Muslim seutuhnya, mengembangkan seluruh potensi manusia baik yang berbentuk jasmani maupun rohani. ${ }^{11}$ Dari pengertian di atas dapat diambil kesimpulan bahwa pendidikan agama Islam diarahkan pada terbentuknya kepribadian Muslim. Kepribadian Muslim adalah pribadi yang menjadikan ajaran Islam sebagai sebuah pandangan hidup, sehingga cara berpikir, merasa, dan bersikap sesuai dengan ajaran Islam.

Pendidikan agama Islam selaras dengan tujuan pendidikan Islam seperti yang diuraikan oleh Yusuf Qardhawi yaitu untuk mengarahkan, membimbing dan mewujudkan manusia seutuhnya; akal dan hatinya, rohani dan jasmaninya, akhlak dan keterampilannya, sehingga mereka (peserta didik) siap menjalani kehidupan dengan baik,

${ }^{8}$ Ibid., 221

${ }^{9}$ Abdul Rachman Assegaf, Aliran Pemikiran Pendidikan Islam; Hadhrah Keilmuan Tokoh Klasik sampai Modern, (Jakarta: Rajawali Press, 2013), 73

${ }^{10}$ Zakiyah Daradjad, Metode Khusus Pengajaran Agama Islam, (Jakarta: Bumi Aksara, 1995), 172

${ }^{11}$ Haidar Putra Daulay, Pendidikan Islam, (Jakarta: Kencana, 2004), 153 
Jurnal Ilmiah "Kreatif" Vol. X No. 2 Juli 2015

"Iurnal Studi Pemikiran Pendidikan Agama Islam"

kapan dan di manapun berdasarkan nilai-nilai Islam. ${ }^{12}$ Dalam bahasa yang berbeda, A. Yusuf Ali menyatakan bahwa pendidikan Islam harus dapat memenuhi 3 (tiga) kebutuhan dasar manusia, yaitu; kebutuhan spiritual, kebutuhan psikologis/intelektual dan kebutuhan fisik/biologis. ${ }^{13}$

Usaha untuk memenuhi tiga kebutuhan di atas, menjadi pertimbangan utama proses pendidikan Islam, khususnya dalam menentukan nilai-nilai dasar yang akan ditransformasikan kepada peserta didik. Sebab salah satu fungsi pendidkan adalah mentransformasikan nilai-nilai. Dalam konteks pendidikan Islam, nilainilai yang dimaksud adalah nilai yang bersumber dari Islam.

Nilai-nilai dasar mencerminkan totalitas sebuah sistem. Menurut Milton dan James Bank, nilai adalah suatu tipe kepercayaan yang berada dalam ruang lingkup sistem kepercayaan, kapan seseorang harus bertindak atau menghindari suatu tindakan, atau mengenai sesuatu yang pantas atau tidak pantas dikerjakan, dimiliki atau dipercayai. ${ }^{14}$ Nilai merupakan preferensi yang tercermn dari perikalu seseorang sehingga ia melakukan atau tidak melakukan sesuatu. Dalam kaitan ini, nilai adalah konsep, sikap dan keyakinan seseorang terhadap sesuatu yang dipandang berharga olehnya. ${ }^{15}$

Terkait dengan nilai yang penting untuk ditanamkan pada siswa yaitu: Pertama, nilai ketauhidan. Adapun nilai ini erat kaitannya dengan Tuhan. Hal yang semestinya dikembangkan dalam diri anak didik adalah terbangunnya pikiran, perkataan dan tindakan anak didik yang diupayakan senantiasa berdasarkan nilai-nilai ketuhanan atau yang bersumber dari ajaran agama yang dianutnya. Sehingga agama yang dianut benar-benar dipahami dan diamalkan dalam kehidupan seharihari. Penanaman nilai ketauhidan pada anak didik ini harus dikembangkan karakternya agar benar-benar berkeyakinan, bersikap, berkata-kata, dan berperilaku sesuai dengan norma agama Islam. ${ }^{16}$

Kedua, nilai humanisme teosentris. Nilai mengandung dua arah pengembangan, yaitu; (1) diinternalisasikan ke dalam diri anak didik dan; (2) diaktualisasikan pada lingkungan sosial. Dalam diri anak

12 Yusuf Qardhawi, Pendidikan Islam dan Madrasah Hasan al-Banna, (Jakarta: Bulan Bintang, 1980), 157

${ }^{13}$ A. Yusuf Ali, The Holy Qur'an, (Maryland: Ali Rajhi Company, 1983),

922-931

${ }^{14}$ Una Kartawirasta, Strategi Klasifikasi Nilai, (Jakarta: P3P, 1984), 1

${ }^{15}$ Ibid., 2

${ }^{16}$ Akhmad Muhaimin Azzet, Urgensi Pendidikan Karakter di Indonesia, (Yogyakarta: ar-Ruzz Media, 2011), 88 
Jurnal Ilmiah "Kreatif" Vol. X No. 2 Juli 2015

"Jurnal Studi Pemikiran Pendidikan Agama Islam"

didik juga dikembangkan untuk menghargai diri sendiri dan orang lain. Menghargai diri sendiri seperti kejujuran. Inilah salah satu hal mendasar dalam kepribadian manusia. Perilaku jujur ini didasarkan pada upaya menjadikan dirinya sebagai orang yang selalu dapat dipercaya, baik terhadap dirinya sendiri maupun orang lain. Tanpa adanya kejujuran, manusia sudah tidak mempunyai nilai kebaikan dihadapan orang lain. Oleh karena itu, nilai kejujuran ini harus dibangun sejak dini pada anak didik. Selain kejujuran, diperlukan juga untuk menumbuhkan rasa tanggung jawab, kerja keras, kepercayaan diri dan disiplin. Disamping itu, nilai yang nantinya akan diaktualisasikan dalam kehidupan sosial adalah penghargaan terhadap sesama. Nilai ini penting ditanamkan agar anak didik dapat mempersiapkan diri untuk berkehidupan sosial. Menghargai orang lain dengan kesadaran akan hak dan kewajibannya sebagai makhluk sosial. ${ }^{17}$

Ketiga, nilai adab dan akhlak. konsepsi pendidikan Islam, meletakkan adab dan akhlak sebagai fondasinya. Adab dan akhlak hendaknya tidak dipahami sebagai dasar-dasar moral tanpa bentukbentuk praktis dalam kehidupan keseharian. Sebagaimana adab dan akhlak juga tidak boleh dipahami sebatas tata krama dan etika praktis, sehingga tidak menyentuh nilai-nilai kecendikiawanan dan tradisi keintelektualan yang menjadi basis bagi perkembangan ilmu pengetahuan. Apa yang dimaksud dengan adab dan akhlak di sini adalah kualitas-kualitas mental, spiritual, sikap dan perilaku dan yang mencakup itu semua. Pendidikan Islam meletakkan nilai adab dan akhlak dalam posisi yang sangat sentral. Penekanan pada aspek adab dan akhlak dalam penanaman nilai pendidikan Islam tersebut tampaknya karena, dalam perspektif Islam, belajar bukanlah demi dan untuk belajar itu sendiri. Tetapi belajar dianggap sebagai bagian dari usaha mendapat hidayah. Ilmu bahkan dipersepsikan sebagai bagian dari hidayah itu sendiri. ${ }^{18}$

Di sinilah salah satu perbedaan antara pendidikan yang dikembangkan oleh negara (baca: umum) dengan pendidikan Islam. Dalam pendidikan Islam, aksiologi ilmu justru diletakkan di urutan terakhir. Tradisi intelektual dan kecendikiawanan yang seharusnya ditanamkan sejak dini, baru ditanamkan ketika peserta didik menginjak bangku kuliah. Tugas mengkaji, metodologi penelitian, kemampuan berpikir kritis dan logis, objektif dalam menilai, jujur, sportif, dan sebagainya akan diberikan pada usia dewasa. Padahal, jika benar-benar

${ }^{17}$ Ibid., 93-96

18 Tobroni, Pendidikan Islam; Paradigma Teologis, Filosofis dan Spiritualis, (Malang: UMM Press, 2008), 71 
Jurnal Ilmiah "Kreatif" Vol. X No. 2 Juli 2015

"Jurnal Studi Pemikiran Pendidikan Agama Islam"

menginginkan agar nilai-nilai tersebut dapat tertanam dalam sikap dan prilaku peserta didik, seharusnyalah sudah ditekankan lebih awal. Berdasarkan pemikiran tersebut, cara yang cukup tepat adalah mengoptimalkan peran serta guru pendidikan Agama Islam sebagai perantara untuk melakukan transformasi nilai yang dimaksud.

\section{Transformasi Nilai-Nilai Keislaman oleh Guru Pendidikan Agama Islam}

Guru memiliki banyak tugas, baik yang terikat oleh dinas maupun di luar dinas, dalam bentuk pengabdian. Ada tiga jenis tugas guru, yakni tugas dalam bidang profesi (mendidik, mengajar, dan melatih), bidang kemanusiaan (menjadi orang tua kedua), bidang kemasyarakatan (mencerdaskan bangsa Indonesia). ${ }^{19}$ Keberadaan guru bagi suatu bangsa dan peradaban sangat penting. Terlebih lagi kemajuan zaman dengan teknologi yang semakin canggih dan segala perubahan serta pergeseran nilai yang cenderung memberi nuansa bagi kehidupan yang menuntut ilmu dan kualitas yang lebih tangguh. Kedudukan guru senantiasa relevan dengan zaman dan sampai kapanpun diperlukan peran dan fungsi edukatifnya.

Tugas guru bukan hanya membuat anak pandai saja, melainkan membekali mereka dengan nilai-nilai kehidupan yang mempersiapkan mereka menjadi insan yang bertanggungjawab, kerja sama, jujur, hemat, teliti, terampil berbicara di depan publik, dan sebagainya.

Guru agama Islam berbeda dengan guru-guru bidang studi lainnya. Guru agama disamping melaksanakan tugas pengajaran, yaitu memberitahukan pengetahuan keagamaan, ia juga melaksanakan tugas pendidikan dan pembinaan bagi peserta didik, membantu pembentukan kepribadian, pembinaan akhlak, di samping menumbuhkan dan mengembangkan keimanan dan ketakwaan peserta didik. ${ }^{20}$

Terkait pembinaan akhlak penekanan pendidikan agama pada siswa, karena hal itu bertujuan untuk membentuk adab dan akhlak yang baik. Ibnu Sina juga menyatakan bahwa kehidupan itu adalah akhlak,

\footnotetext{
Press, 2010), 73

${ }^{20}$ Zakiyah Darajat, Pendidikan Islam dalam Keluarga dan Sekolah, (Jakarta: Ruhama, 1995), 99
}

19 Asep Umar Fachruddin, Menjadi Guru Favorit, (Yogyakarta: Diva 
Jurnal Ilmiah "Kreatif" Vol. X No. 2 Juli 2015 "Jurnal Studi Pemikiran Pendidikan Agama Islam"

tiada kehidupan tanpa akhlak yang baik. Di samping itu, akhlak dapat memberikan kontribusi positif terhadap perkembangan fisik dan psikologi siswa. Penekanan terhadap akhlak ini juga sudah ada semenjak zaman Yunani demi memberi kebaikan kepada pembentukan suatu bangsa. ${ }^{21}$

Pendidikan agama Islam memiliki karakteristik tersendiri yang berbeda dengan mata pelajaran lainnya, yaitu: (1) PAI berusaha untuk menjaga akidah peserta didik agar tetap kokoh dalam situasi dan kondisi apapun; (2) PAI berusaha menjaga dan memelihara ajaran dan nilai-nilai yang tertuang dan terkandung dalam al-Qur'an dan hadis serta otensitas keduanya sebagai sumber utama ajaran Islam; (3) PAI mnonjolkan kesatuan iman, ilmu dan amal dalam kehidupan keseharian; (4) PAI berusaha membentuk dan mengembangkan kesalehan individual dan kesalehan sosial; (5) PAI menjadi landasan moral dan etika dalam pengembangan IPTEKS dan budaya serta aspek-aspek kehidupan lainnya; (6) substansi PAI mengandung entitas-entitas yang bersifat rasional dan supra-rasional; (7) PAI berusaha menggali, mengembangkan dan mengambil ibrah dari sejarah dan kebudayaan (peradaban) Islam; dan (8) dalam beberapa hal, PAI mengandung pemahaman dan penafsiran yang beragam, sehingga memerlukan sikap terbuka dan toleran atau semangat ukhuwah Islamiyah. ${ }^{22}$

Pendidikan agama Islam hendaknya bukan saja berusaha meningkatkan kesadaran beragama, tetapi juga untuk melihat perubahanperubahan sosial dalam perspektif transendental, dan menempatkan iman sebagai sumber motivasi perkembangan dalam menyelami dan menghayati ilmu pengetahuan modern. Ini berarti bahwa dalam proses pendidikan Islam terkandung upaya peningkatan kemampuan mengintegrasikan akal dengan nurani dalam menghadapi masalah perubahan sosial.

Dengan demikian, diharapkan pendidikan agama Islam dapat memenuhi fungsi yang luhur dalam menghadapi perkembangan sosial, apabila dalam proses belajar mengajar menggunakan pola pengajaran inovative learning, yakni: (1) Berusaha memupuk motivasi yang kuat

${ }^{21}$ Abdul Rachman Assegaf, Aliran Pemikiran..., 97-98

${ }^{22}$ Muhaimin, Pemikiran dan Aktualisasi Pengembangan Pendidikan Islam, (Jakarta: Rajawali Press, 2011), 183-184 
Jurnal Ilmiah "Kreatif" Vol. X No. 2 Juli 2015 "Jurnal Studi Pemikiran Pendidikan Agama Islam"

kepada peserta didik untuk mempelajari dan memahami kenyataankenyataan sosial yang ada. (2) Berusaha memupuk sikap berani menghadapi tantangan hidup, kesanggupan untuk mandiri dan berinisiatif, peka terhadap kepentingan sesama manusia dan sanggup bekerja secara kolektif dalam suatu perubahan sosial. ${ }^{23}$

\section{Simpulan}

Guru PAI memiliki kewajiban untuk menanamkan nilai-nilai islam kepada peserta didik. Mempersiapkan peserta didik untuk menghadapi perubahan sosial sesuai dengan nilai yang diajarkan sebagai landasan berperilaku dan bertindak di masyarakat. Peserta didik diharapkan untuk menjadi kader pembangunan masyarakat yang taat beragama. Dengan kata lain, ia bukan hanya saleh secara individual, melainkan pula menjadi katalisator pembanguan dalam masyarakatnya.

Dalam spketrum yang lebih makro, seberapa jauh alih nilai moral mampu membekali peserta didik untuk menghadapi sekaligus memecahkan persoalan secara proporsional sekaligus mampu mengembangkan budaya religius. Spektrum tersebut menuntut peran guru untuk mampu menyertakan materi-materi yang kontekstual, dinamis dan berorientasi ke masa depan. Semua ini akan didapatkan jika tradisi menyadap banyak informasi menjadi tuntutan setiap saat bagi para guru.

Guru PAI sudah seharusnya memberikan penekanan lebih pada pencapaian kompetensi-kompetensi yang dapat bermanfaat langsung kepada masyarakat, atau biasa disebut kompetensi sosial. Jadi selain membekali peserta didik dengan kompetensi individual, guru PAI juga memberi perhatian pada pencapaian kompetensi sosial tersebut. Dengan begitu, diharapkan pendidikan agama Islam menjadi jalan keluar persoalan yang dihadapi peserta didik dewasa ini seperti narkoba, tawuran antar pelajar dan sebagainya.

${ }^{23}$ M. Zainuddin, Filsafat Ilmu Perspektif Pemikiran Islam, (Yogyakarta: Naila Pustaka, 2011), 158 
Jurnal Ilmiah "Kreatif" Vol. X No. 2 Juli 2015

"Jurnal Studi Pemikiran Pendidikan Agama Islam"

\section{Daftar Pustaka}

Albaroris, Muhyidin dan Sutrisno, Pendidikan Islam Berbasis Problem Sosial, Yogyakarta: Ar-Ruzz Media, 2012.

, Mendidik Generasi Bangsa, Yogyakarta: Pedagogia, 2012.

Mulyasa, E. Standar Kompetensi dan Sertifikasi Guru, Bandung: Remaja Rosdakarya, 2007.

Darajat, Zakiah. Ilmu Pendidikan Islam, Jakarta: Bumi Aksara, 2008.

---------, Metode Khusus Pengajaran Agama Islam, Jakarta: Bumi Aksara, 1995.

--------, Pendidikan Islam dalam Keluarga dan Sekolah, Jakarta: Ruhama, 1995.

Taufiq, Ahmad dan Rohmadi, Muhammad (ed), Pendidikan Agama Islam, Surakarta: Yuma Pustaka, 2011.

Assegaf, Abdul Rachman, Aliran Pemikiran Pendidikan Islam; Hadhrah Keilmuan Tokoh Klasik sampai Modern, Jakarta: Rajawali Press, 2013.

Daulay, Haidar Putra. Pendidikan Islam, Jakarta: Kencana, 2004.

Qardhawi, Yusuf. Pendidikan Islam dan Madrasah Hasan al-Banna, Jakarta: Bulan Bintang, 1980.

Ali, A. Yusuf, The Holy Qur'an, Maryland: Ali Rajhi Company, 1983.

Kartawirasta, Una. Strategi Klasifikasi Nilai, Jakarta: P3P, 1984.

Azzet, Akhmad Muhaimin. Urgensi Pendidikan Karakter di Indonesia, Yogyakarta: ar-Ruzz Media, 2011.

Tobroni, Pendidikan Islam; Paradigma Teologis, Filosofis dan Spiritualis, Malang: UMM Press, 2008.

Fachruddin, Asep Umar. Menjadi Guru Favorit, Yogyakarta: Diva Press, 2010.

Muhaimin, Pemikiran dan Aktualisasi Pengembangan Pendidikan Islam, Jakarta: Rajawali Press, 2011.

Zainuddin, M. Filsafat Ilmu Perspektif Pemikiran Islam, Yogyakarta: Naila Pustaka, 2011. 